\title{
SENSITIVITY ANALYSIS OF A TPB DEGRADATION RATE MODEL
}

Charles L. Crawford

Thomas B. Edwards

William R. Wilmarth

August 2006

Statistical Consulting Section

Savannah River National Laboratory

Aiken, SC 29808

Prepared for the U.S. Department of Energy Under Contract Number DEAC09-96SR18500

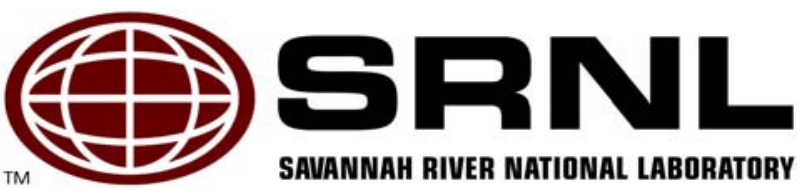




\section{DISCLAIMER}

This report was prepared by Washington Savannah River Company (WSRC) for the United States Department of Energy under Contract No. DE-AC09-96SR18500 and is an account of work performed under that contract. Neither the United States Department of Energy, nor WSRC, nor any of their employees makes any warranty, expressed or implied, or assumes any legal liability or responsibility for the accuracy, completeness, or usefulness, of any information, apparatus, or product or process disclosed herein or represents that its use will not infringe privately owned rights. Reference herein to any specific commercial product, process, or service by trademark, name, manufacturer or otherwise does not necessarily constitute or imply endorsement, recommendation, or favoring of same by WSRC or by the United States Government or any agency thereof. The views and opinions of the authors expressed herein do not necessarily state or reflect those of the United States Government or any agency thereof.

\section{Printed in the United States of America \\ Prepared For U.S. Department of Energy}

The Savannah River National Laboratory is operated for the U.S. Department of Energy by Washington Savannah River Company. 
Key Words: statistics, uncertainty, model predictions, Tank 48

\author{
Retention: Permanent
}

\title{
SENSITIVITY ANALYSIS OF A TPB DEGRADATION RATE MODEL
}

Charles L. Crawford

Thomas B. Edwards

William R. Wilmarth

August 2006

Statistical Consulting Section

Savannah River National Laboratory

Aiken, SC 29808

Prepared for the U.S. Department of Energy Under Contract Number DEAC09-96SR18500

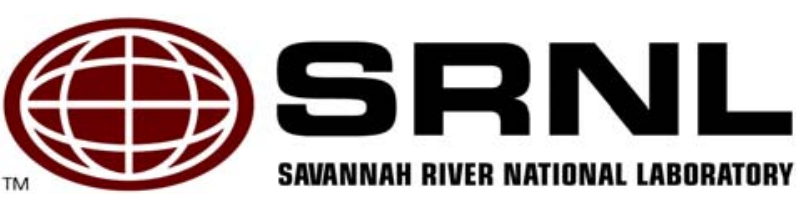




\section{REVIEWS AND APPROVALS}

\section{AUTHORS:}

¿. L. Crawford, Process Science and Engineering $\frac{8-03-06}{\text { Date }}$

T. B. Edwărds, Statistical Consulting

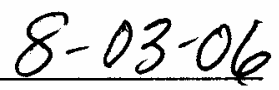

Date

$$
8-3-0 Z
$$

W. R. Wilmarth, Chemical Science and Technology

Date

\section{TECHNICAL REVIEWER:}

$8 / 3 / 06$
S. P. Hate

\section{APPROVERS:}
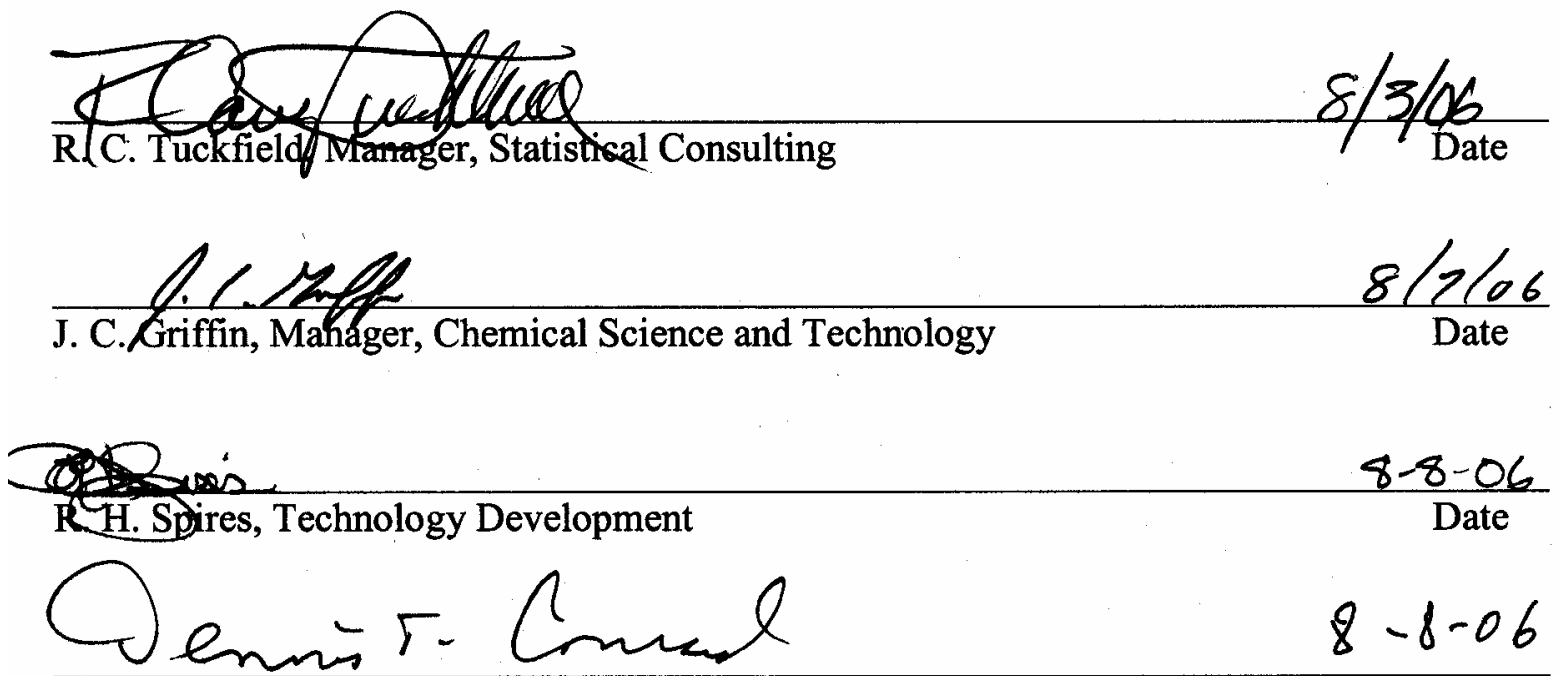

D. T. Conrad, Salt Processing Design Authority

Date




\section{EXECUTIVE SUMMARY}

A tetraphenylborate (TPB) degradation model for use in aggregating Tank 48 material in Tank 50 is developed in this report. The influential factors for this model are listed as the headings in the table below. A sensitivity study of the predictions of the model over intervals of values for the influential factors affecting the model was conducted. These intervals bound the levels of these factors expected during Tank 50 aggregations. The results from the sensitivity analysis were used to identify settings for the influential factors that yielded the largest predicted TPB degradation rate. Thus, these factor settings are considered as those that yield the "worst-case" scenario for TPB degradation rate for Tank 50 aggregation, and, as such they would define the test conditions that should be studied in a waste qualification program whose dual purpose would be the investigation of the introduction of Tank 48 material for aggregation in Tank 50 and the bounding of TPB degradation rates for such aggregations.

The recommended conditions for testing the decomposition of Tank 48 waste slurries in a waste qualification program are:

\begin{tabular}{||c|c|c|c|c|c||}
\hline $\begin{array}{c}\text { Temperature } \\
\left({ }^{\mathbf{}} \mathbf{C}\right)\end{array}$ & $\mathbf{p H}$ & $\begin{array}{c}\text { Na+ } \\
(\mathbf{M})\end{array}$ & $\mathbf{w t} \%$ KTPB & $\begin{array}{c}\text { Rad/ } \\
\text { No Rad }\end{array}$ & $\begin{array}{c}\text { Soluble } \\
\text { TPB } \\
\text { Present }\end{array}$ \\
\hline 45 & 14 & 6 & 0.1 & $\mathrm{Rad}$ & No \\
\hline
\end{tabular}

For these settings of the influential factors, the model yields the highest expected TPB rate with a value of $2.04 \times 10^{-6}$ mole $\mathrm{KTPB} / \mathrm{L} /$ day. Since the rate used in the modeling is expressed as a natural logarithm $(\ln [$ rate $])$, the expected value of the model may be thought of as the average of the $\ln [$ rate]'s that would be generated by running a series of experiments - all at the conditions specified in the table above. The upper bound on this expected rate, at $95 \%$ confidence, is given by $4.95 \times 10^{-6}$ mole $\mathrm{KTPB} / \mathrm{L} /$ day. 
WSRC-TR-2006-00161

Revision 0

This page intentionally left blank. 


\section{TABLE OF CONTENTS}

EXECUTIVE SUMMARY iii

List of Tables vi

List of Figures $\quad$ vi

List of Acronyms

vi

1.0 INTRODUCTION AND BACKGROUND

2.0 RESULTS

3.0 RECOMMENDED SETTINGS

4.0 CONCLUSIONS

5.0 REFERENCES 


\section{LIST OF TABLES}

Table 2-1. Minimum and Maximum Factor Levels............................................................ 2

Table 2-2. Initial Intervals for Sensitivity Study of the TPB Model ....................................... 5

Table 2-3 Actual Intervals for Sensitivity Study of the TPB Model ....................................... 7

\section{LIST OF FIGURES}

Figure 2-1. Legend of Symbols/Colors Used to Represent Experimental Results .................. 3

Figure 2-2. A Set of Box Plots Showing the $\ln ($ rate) Values Grouped by Rad vs Non-Rad and Soluble TPB Present vs Not Present .................................................................... 3

Figure 2-3 $\ln ($ rate) Prediction Formula for TPB Model........................................................ 4

Figure 2-4 Scatterplot Matrix for Grid Outlined in Table 2-2 .............................................. 6

Figure 2-5 TPB Model Predictions by Factor for Grid Outlined in Table 2-2 ........................ 7

Figure 2-6 Scatterplot Matrix for Grid Outlined in Table 2-3 ................................................. 8

Figure 2-7 TPB Model Predictions by Factor for Grid Outlined in Table 2-3 ....................... 9

\section{LIST OF ACRONYMS}

DSS Decontaminated Salt Solution

DWPF Defense Waste Processing Facility

HLW High Level Waste

JMP Pronounced “jump." It's a statistical software package, a registered trademark of SAS Institute, Inc.

MCU Modular Caustic Side Solvent Extraction Unit

MDL Minimum Detection Limit

RMSE Root Mean Square Error

SRNL Savannah River National Laboratory

SRS Savannah River Site

TPB Tetraphenylborate 


\subsection{INTRODUCTION AND BACKGROUND}

Options are currently under study for returning the H-area's Tank 48 to service by disposing of its current $\sim 250,000$ gallons of salt solution which contains $21,800 \mathrm{~kg}$ of potassium $(\mathrm{K})$ and cesium (Cs) tetraphenylborate (TPB) [1]. One option that has been explored is the aggregation of the Tank 48 material in Tank 50 with Defense Waste Processing Facility (DWPF) recycle material and decontaminated salt solution (DSS) from the Modular Caustic Side Solvent Extraction Unit (MCU). The available data on decomposition rates for potassium tetraphenylborate (KTPB) solids have been fitted to statistical models in an effort to derive expressions of the solids decomposition rate as a function of a number of variables including sodium ion concentration, temperature, $\mathrm{pH}$, wt \% KTPB, etc. (see References [2] and [3] for background information of the data and model discussed in this paper). A model was initially developed to predict the TPB decomposition rate for conditions anticipated for the Tank 48 residual heel. After the model was developed it was also considered for predictions of TPB decomposition under conditions anticipated during the aggregation of Tank 48 material in Tank 50.

A waste qualification program is to be developed to validate that the degradation rates for the planned Tank 50 aggregation streams will be below levels of concern with high confidence before actual aggregation would be conducted. The waste qualification program is to be an experimental study, and for it to be successful it is necessary to define an appropriate experimental protocol to represent the planned aggregations. This includes establishing settings for the levels of the influential inputs to the degradation process as anticipated by the model described below.

This technical report is being prepared to document an important input to the planning of the waste qualification program. The purpose of the paper is to document the data used in model development, the fitted model to be used to predict TPB degradation rate, and a sensitivity study for the predictions of the model over intervals of values for its respective influential factors. The results from the sensitivity analysis are to be used to identify settings for the influential factors that are to be studied as part of the waste qualification program. To accomplish this, the predicted rates for TPB decomposition for the model are to be explored over a range of conditions of interest, the maximum predicted TPB decomposition rate for the model over a range of conditions of interest is to be determined, and the settings (i.e., the values of the influential factors) for the maximum rate are to be identified.

\subsection{RESULTS}

The data in Table A1 of Appendix A provide the set of experimental outcomes that was compiled from available studies to support this modeling effort. Reference [2] provides the details associated with the compilation of these data. As the data were evaluated during this process, an attempt was made to reconcile experimental outcomes which were below the measurement detection limit (MDL) of the analytical process. These situations are identified by an entry of "MDL" in the "Notes" column of Table A1. There are also some entries in this table that reflect experiments with outcomes that were above the upper limit of the analytical process. These are indicated in the table by the label "Pegged high." The model discussed in this paper, however, was based on all of the data of Table A1.

In Table A1, there are columns for the quantitative factors: “Temp" (temperature in ${ }^{\circ} \mathrm{C}$ ), $\mathrm{pH}$, weight percent potassium TPB (wt $\% \mathrm{KTPB}$ ), and $\mathrm{Na}^{+}$concentration (in moles/Liter, or Molar (M)) and qualitative factors: Rad/No Rad (radioactive or non-radioactive experimental trials) and 
TPB Present (yes or no for the presence of soluble TPB in the experiment trial). A "no" for this last variable indicates that the amount of soluble TPB present, if any is present, is below $10 \mathrm{mg} / \mathrm{L}$, the nominal DL of High Pressure Liquid Chromatography (HPLC). The TPB rate is the response of interest in Table A1. The values are expressed in the units E-06 moles of KTPB/L/day. A column also identifies if the testing involved a simulant or an actual high level waste (HLW) tank sample. Table 2-1 provides the minimum ( $\mathrm{min}$ ) and maximum ( $\max$ ) values for the quantitative factors for different groupings of the experiments. These data show that 127 data points, or observations, were considered. The temperatures ranged from $25^{\circ} \mathrm{C}$ to $75^{\circ} \mathrm{C}$, the $\mathrm{pH}$ 's ranged from 7 to 14.5 , the $\mathrm{wt} \% \mathrm{KTPB}$ ranged from $0.0034 \mathrm{wt} \%$ to $5 \mathrm{wt} \%$ and the sodium molarity ranged from 0.1 to $8.58 \mathrm{M}$.

Table 2-1. Minimum and Maximum Factor Levels

\begin{tabular}{|c|c|c|c|c|c|c|c|c|}
\hline & & No Rad & No Rad & No Rad & $\operatorname{Rad}$ & Rad & Rad & \\
\hline \multicolumn{2}{|c|}{ Soluble TPB Present } & No & Yes & Both & No & Yes & Both & Overall \\
\hline \multicolumn{2}{|c|}{ Number of Observations } & 31 & 34 & 65 & 30 & 32 & 62 & 127 \\
\hline \multirow{2}{*}{$\begin{array}{c}\text { Temperature } \\
\left({ }^{\circ} \mathrm{C}\right)\end{array}$} & $\min$ & 25 & 25 & 25 & 25 & 30 & 25 & 25 \\
\hline & $\max$ & 60 & 70 & 70 & 75 & 64 & 75 & 75 \\
\hline \multirow{2}{*}{$\mathrm{pH}$} & $\min$ & 7 & 10.1 & 7 & 11 & 9.8 & 9.8 & 7 \\
\hline & $\max$ & 14 & 14.5 & 14.5 & 14.5 & 14.5 & 14.5 & 14.5 \\
\hline \multirow{2}{*}{$w t \%$ KTPB } & $\min$ & 0.2147 & 2.6 & 0.2147 & 0.0034 & 0.8 & 0.0034 & 0.0034 \\
\hline & $\max$ & 2.32 & 5 & 5 & 2.06 & 5 & 5 & 5 \\
\hline \multirow{2}{*}{$\mathrm{Na}^{+}(\mathrm{M})$} & $\min$ & 2 & 0.1 & 0.1 & 0.14 & 0.1 & 0.1 & 0.1 \\
\hline & $\max$ & 5.6 & 5.5 & 5.6 & 8.58 & 5.5 & 8.58 & 8.58 \\
\hline
\end{tabular}

Before moving on to the discussion of model development, there is a need to carefully frame how the model predictions are going to be used. Note that the response used in the models developed in this study is the natural logarithm of the TPB rates of Table A1. JMP Version 5.1.2 from SAS Institute, Inc. [4] was used to conduct the statistical modeling. Statistical science provides several different types of confidence intervals for a predictive model like the one developed in this report. For the purposes of this report, the bound of interest is an upper $95 \%$ confidence limit on the expected log TPB rate for a single set of aggregation conditions (the two-sided version of this interval is available as a JMP option).

Figure 2-1 provides the legend of symbols and colors used to represent the experimental results in the plots used for model fitting. The main scheme used is to separate the Rad versus No Rad and the TPB Present versus Not Present data. A designation between simulant versus HLW tests is also incorporated in the legend. In addition there is one data point in Table A1 with an estimated TPB rate of 14,821 ( $\times$ E-06 moles of KTPB/L/day) that was identified as a questionable result. This value is represented by a unique symbol and color (it is a No Rad/No TPB Present experimental result) so that its location on the various plots can be readily seen. 
WSRC-TR-2006-00161

Revision 0

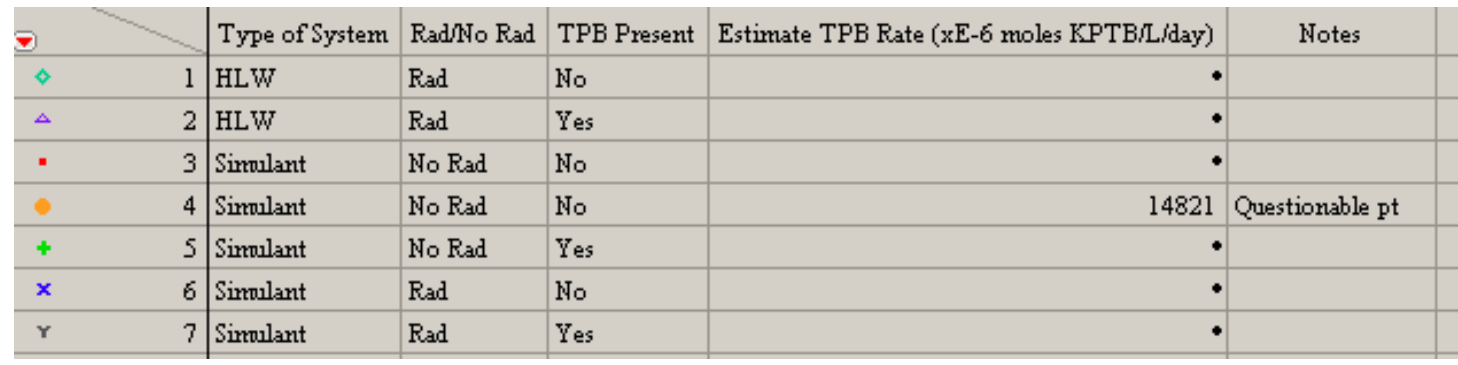

Figure 2-1. Legend of Symbols/Colors Used to Represent Experimental Results

Figure 2-2 provides a look at the (natural logarithm of the) TPB rate data generated by the set of experiments. In this exhibit, a box plot is superimposed on the data. The upper end of each box represents the $75^{\text {th }}$ percentile while the lower end represents the $25^{\text {th }}$ percentile. The solid line crossing each box is the $50^{\text {th }}$ percentile, or median. The horizontal hash mark within the box represents the mean of the data. Each box has lines, sometimes called whiskers, that extend from each end. The whiskers extend from the ends of the box to the outermost data point that falls within the distances computed

upper quartile $+1.5^{*}$ (interquartile range)

lower quartile - $1.5 *$ (interquartile range).

where the interquartile range is equal to the difference between the $25^{\text {th }}$ and $75^{\text {th }}$ percentiles. Data outside of this range are the more extreme values. These box plots show the wide interval of TPB rates (since the $y$-axis for these plots is in log space) that are covered in the experimental outcomes recorded in Table A1.

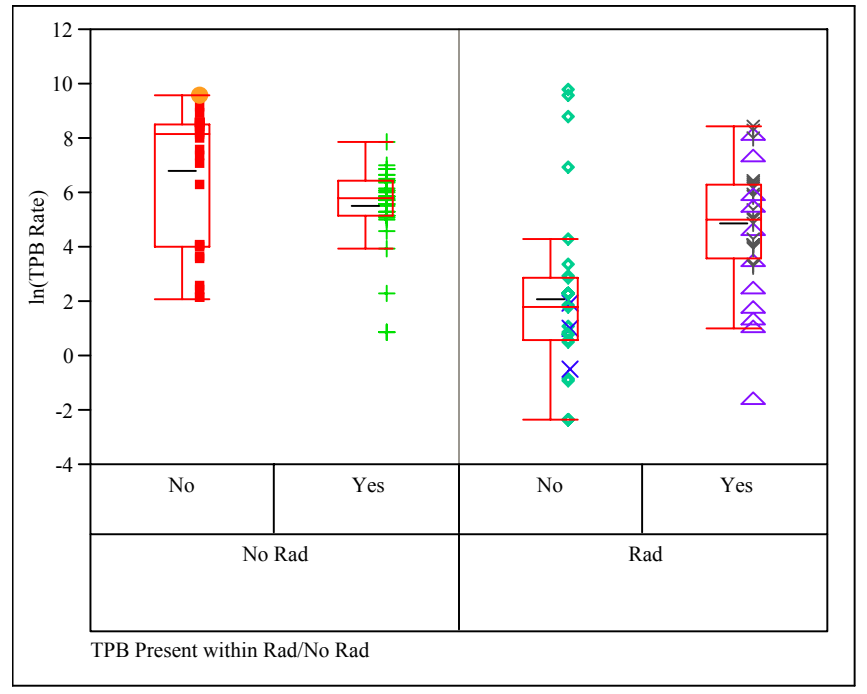

Figure 2-2. A Set of Box Plots Showing the In(rate) Values Grouped by Rad vs Non-Rad and Soluble TPB Present vs Not Present 
It is the sensitivities of the predicted degradation rates for the statistical model that are explored in this study. The prediction equation for the model is provided in Figure 2-3. The degradation rates for the model are predicted as natural logarithms in the units of $10^{-6} \mathrm{~mole} \mathrm{KTPB} / \mathrm{L} / \mathrm{day}$.

All of the data were used in the fitting of the TPB model discussed in this report. A full factorial model of degree 2 involving all of the factors defined the candidate terms that were submitted to JMP's Stepwise regression routine to select the "best subset" of terms for the model. Any interactive terms with p-values much greater than $5 \%$ were removed from the model as well. The JMP results including the p-values for the final model are given in Exhibit A1 in Appendix A. The $\mathrm{R}^{2}$ value for the fitted model is $77.6 \%$ with a root mean square error (RMSE) of 1.462 in log units. There is no indication of a significant lack of fit (at the 5\% significance level) for this model.

Figure 2-3 provides the JMP formula for the model's expected value of the natural logarithm of the TPB rate. Note that the TPB decomposition rate in the units of E- 06 moles of KTPB/L/day is determined by taking the exponential of the model's predicted value. The formula for the predicted log value involves different calculations depending on the values of the qualitative factors (i.e., Rad or Non-rad experiments and TPB Present or Not Present). The options for the calculations are indicated and handled by JMP's "Match" function. Further details of the development of the JMP formula for the model's expected value of the natural logarithm of the TPB rate can be found in Ref. [2].

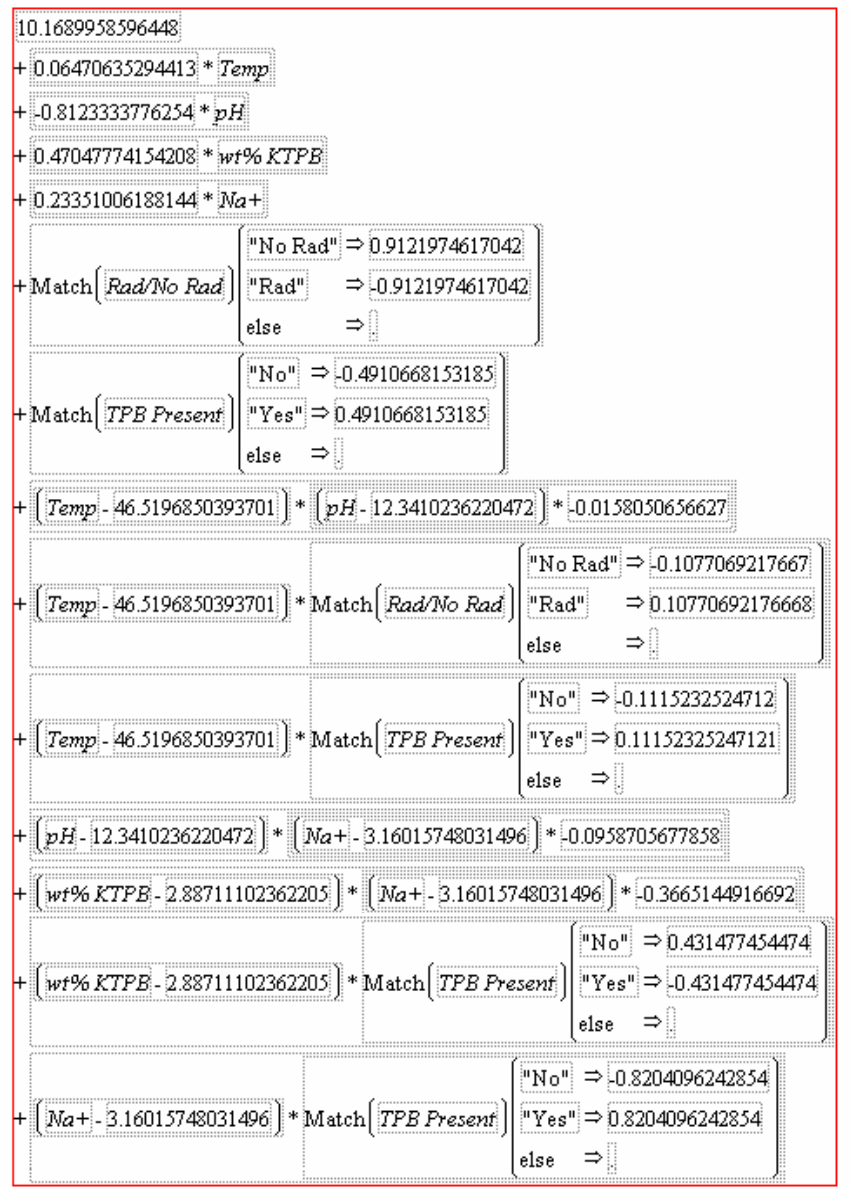

Figure 2-3 $\ln ($ rate) Prediction Formula for TPB Model 
During the development of the aggregation flowsheet in 2005, the intervals of values for temperature, sodium ion concentration $\left(\mathrm{Na}^{+}\right)$, weight percent ( $\left.\mathrm{wt} \%\right) \mathrm{KTPB}$ solids, and $\mathrm{pH}$ for radioactive conditions without any soluble TPB being present at concentrations above $10 \mathrm{mg} / \mathrm{L}$ were evaluated. The intervals, which were derived from this process, include the maximum values from individual streams. The intervals are presented in Table 2-2, and these intervals were used as the initial inputs to the sensitivity analysis for the TPB model.

Table 2-2. Initial Intervals for Sensitivity Study of the TPB Model

\begin{tabular}{|c|c|c|c|}
\hline Factor & Interval of Interest & $\begin{array}{c}\text { Unit of } \\
\text { Measure }\end{array}$ & $\begin{array}{c}\text { Grid } \\
\text { Values }\end{array}$ \\
\hline $\mathrm{Na}^{+}$ & $1 \leq \mathrm{Na}^{+} \leq 7$ & $\mathrm{M}$ & $1,1.5,2,2.5,3,3.5,4,4.5,5,5.5$, \\
$6,6.5,7$
\end{tabular}

The statistical package, JMP ${ }^{\circledR}$ Version 5.1.2 [4] was used to create a grid of points covering the intervals outlined in Table 2-2. Specifically, the grid was created with every possible combination of the values in the right-most column of Table $2-2$; thus, a total of $13 \times 6 \times 6 \times 12=$ 5,616 points defined the grid. Figure $2-4$ provides a scatterplot matrix of pairwise plots of the levels in Table 2-2 outlining the grid. The grid points are shown using the symbol, $\bigcirc$, while the symbol $\square$ is used to represent the factor levels for Tank 50 Batches 2, 10, 20, 30, 40, 48, and 60 as derived from the aggregation flowsheet [1]. 
WSRC-TR-2006-00161

Revision 0

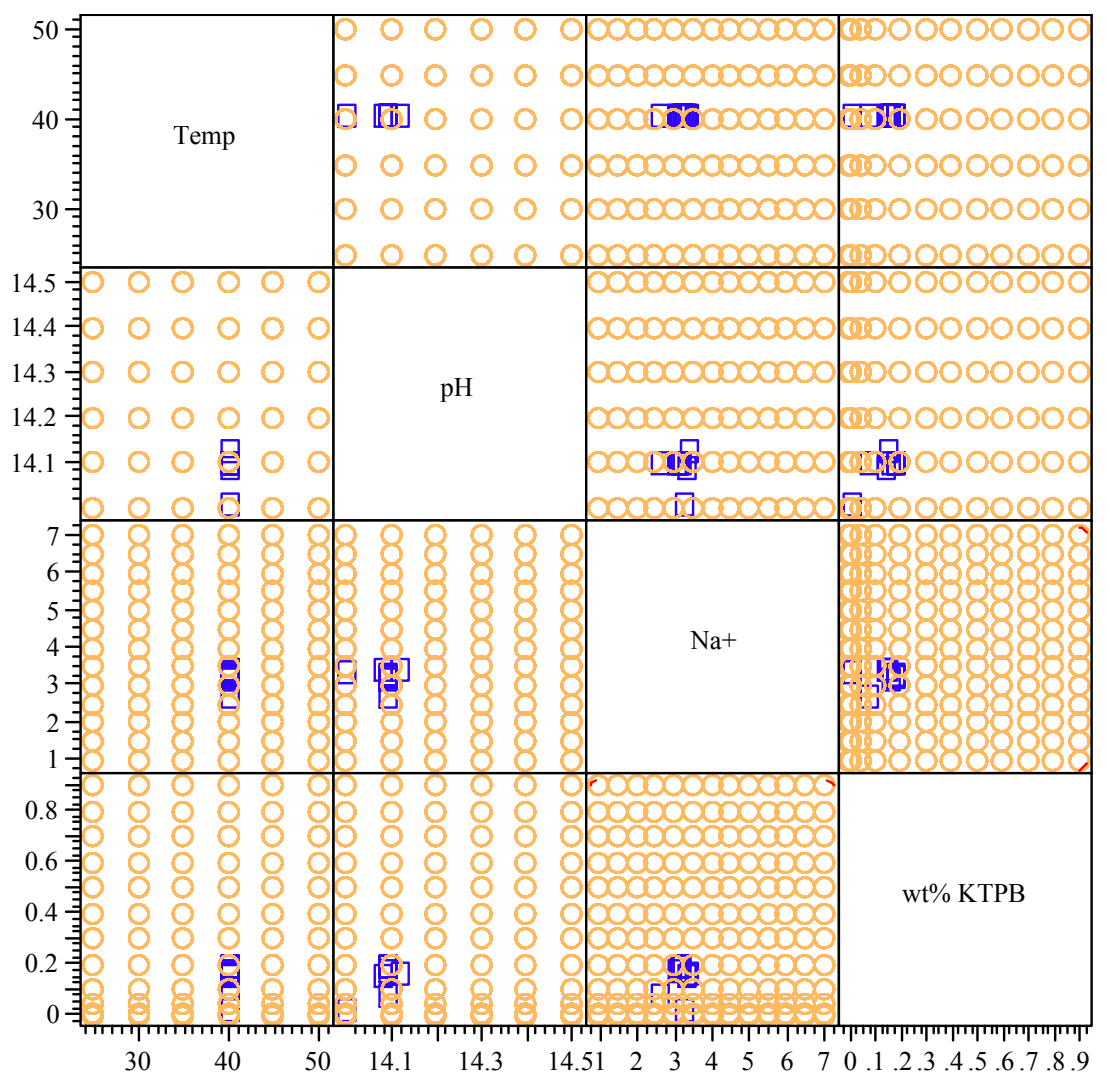

Figure 2-4 Scatterplot Matrix for Grid Outlined in Table 2-2

Using this grid covering the factor space of interest, the TPB model was used to predict the corresponding degradation rates. Figure 2-5 provides a plot of the predicted rates versus the factor levels for each of the four factors: temperature (Temp in $\left.{ }^{\circ} \mathrm{C}\right), \mathrm{pH}, \mathrm{wt} \% \mathrm{KTPB}$, and sodium ion concentration $\left(\mathrm{Na}^{+}\right.$moles/Liter). 
Predicted In(TPB Rate) By Temp

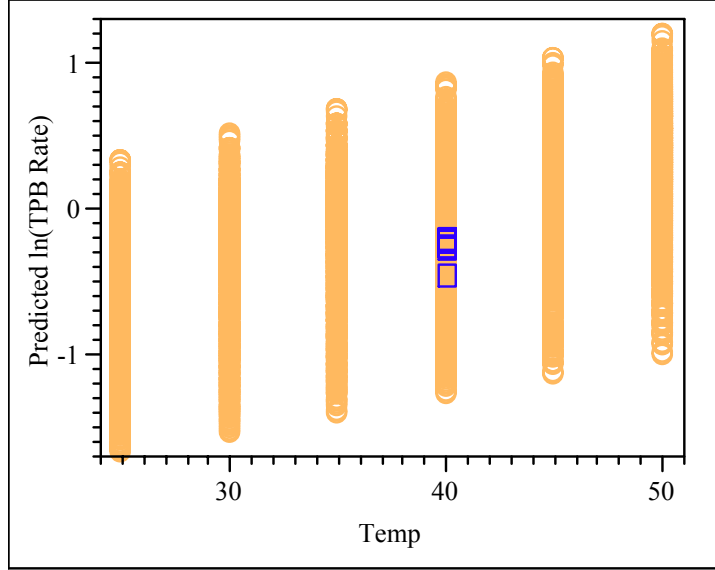

Predicted In(TPB Rate) By pH

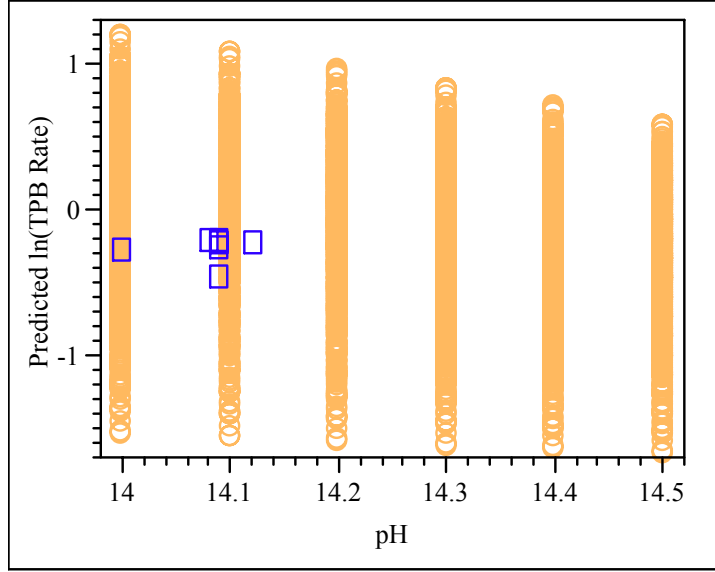

Predicted $\ln (\mathrm{TPB}$ Rate) By Na+
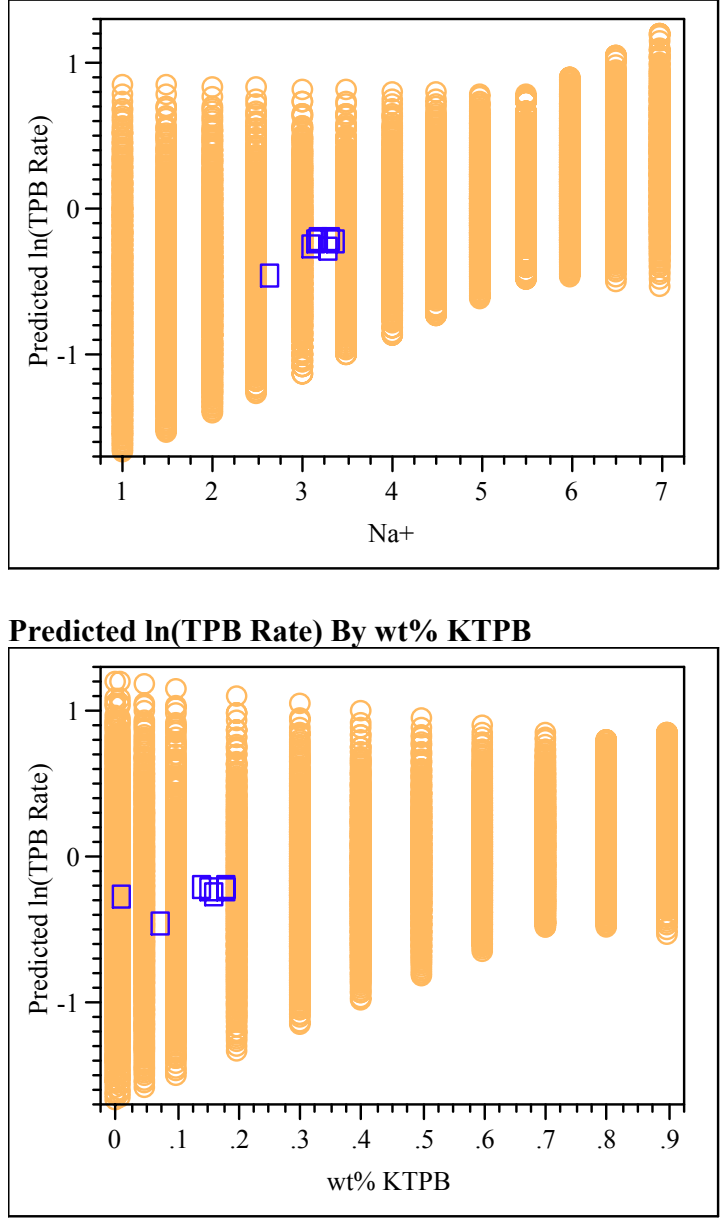

Figure 2-5 TPB Model Predictions by Factor for Grid Outlined in Table 2-2

The review of the model predictions over this grid of points also led to refinements in the flowsheet [1] that yielded the intervals actually used to conduct the sensitivity analysis for TPB model. These actual intervals for the model factors are outlined in Table 2-3.

Table 2-3 Actual Intervals for Sensitivity Study of the TPB Model

\begin{tabular}{|c|c|c|c|}
\hline Factor & Interval of Interest & $\begin{array}{c}\text { Unit of } \\
\text { Measure }\end{array}$ & $\begin{array}{c}\text { Grid } \\
\text { Values }\end{array}$ \\
\hline $\mathrm{Na}^{+}$ & $1 \leq \mathrm{Na}^{+} \leq 6$ & $\mathrm{M}$ & $1,1.5,2,2.5,3,3.5,4,4.5,5,5.5,6$ \\
\hline Temperature & $25 \leq \mathrm{temperature} \leq 45$ & ${ }^{\circ} \mathrm{C}$ & $25,30,35,30,45$ \\
\hline $\mathrm{pH}$ & $14 \leq \mathrm{pH} \leq 14.5$ & $\mathrm{M}$ & $14,14.1,14.2,14.3,14.4,14.5$ \\
\hline $\mathrm{wt} \% \mathrm{KTPB}$ & $0.001 \leq \mathrm{wt} \% \mathrm{KTPB} \leq 0.4$ & $\mathrm{wt} \%$ & $0.001,0.01,0.05,0.1,0.2,0.3,0.4$ \\
\hline $\mathrm{Rad} / \mathrm{No} \mathrm{Rad}$ & $\mathrm{Rad}$ & & \\
\hline $\mathrm{TPB}$ Present/No & $\mathrm{No}$ & & \\
\hline
\end{tabular}


$\mathrm{JMP}^{\circledR}$ was used to create a grid of $11 \times 5 \times 6 \times 7=2310$ points covering the intervals outlined in Table 2-3, and the TPB model was used to predict the degradation rates over this grid of points. Figure 2-6 provides a scatterplot matrix of pairwise plots of the levels in Table 2-3 outlining the grid. As in the earlier plots, the grid points are shown using the symbol, $\bigcirc$, while the symbol is used to represent the factor levels for Tank 50 Batches 2, 10, 20, 30, 40, 48, and 60.

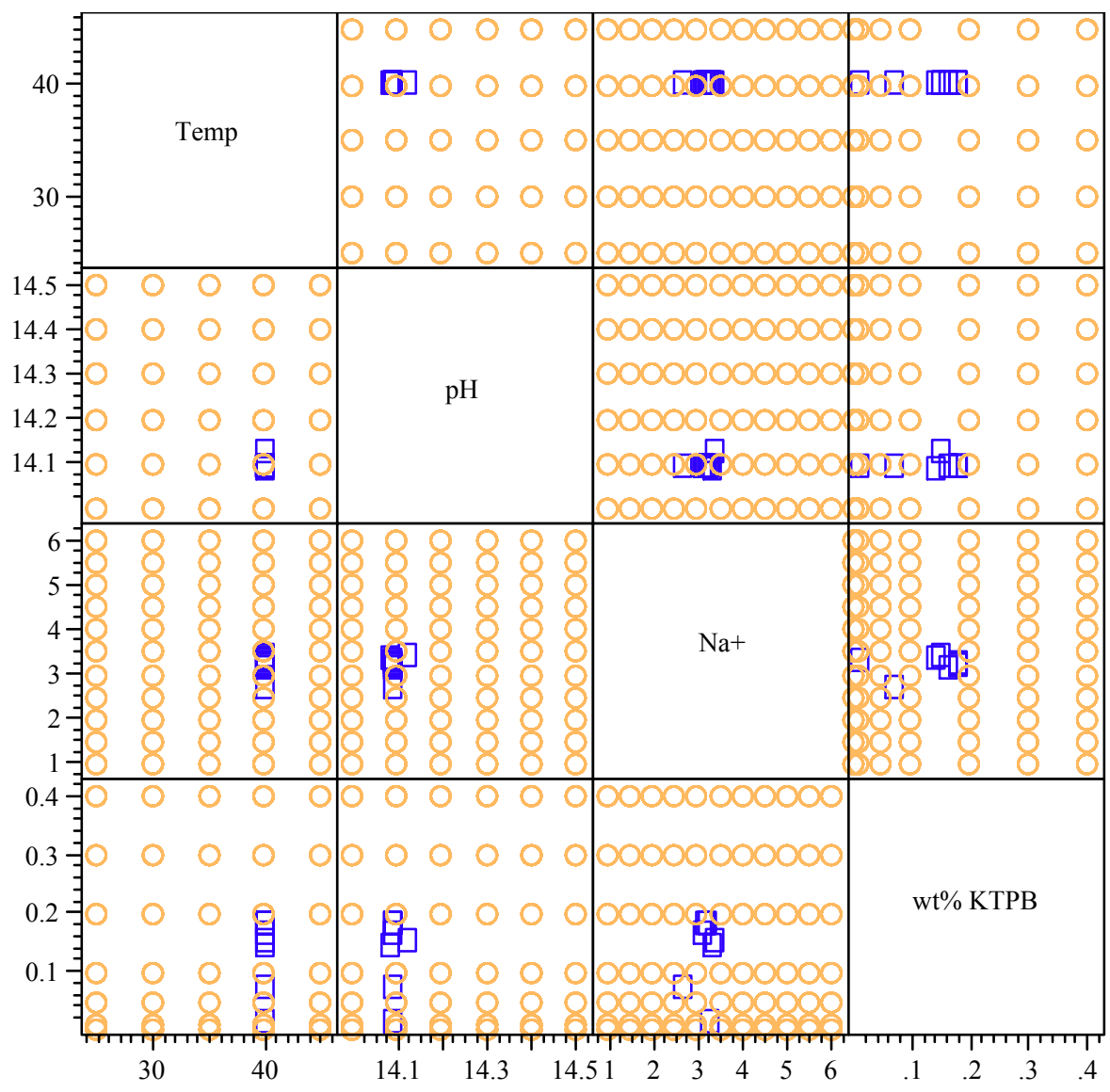

Figure 2-6 Scatterplot Matrix for Grid Outlined in Table 2-3

Using this grid covering the factor space of interest, the TPB model was used to predict the corresponding degradation rates. Figure 2-7 provides a plot of the predicted rates versus the factor levels for each of the four factors: temperature (Temp in $\left.{ }^{\circ} \mathrm{C}\right), \mathrm{pH}$, $\mathrm{wt} \% \mathrm{KTPB}$, and sodium ion concentration $\left(\mathrm{Na}^{+}\right.$in moles/Liter). 
WSRC-TR-2006-00161

Revision 0

Predicted In(TPB Rate) By Temp

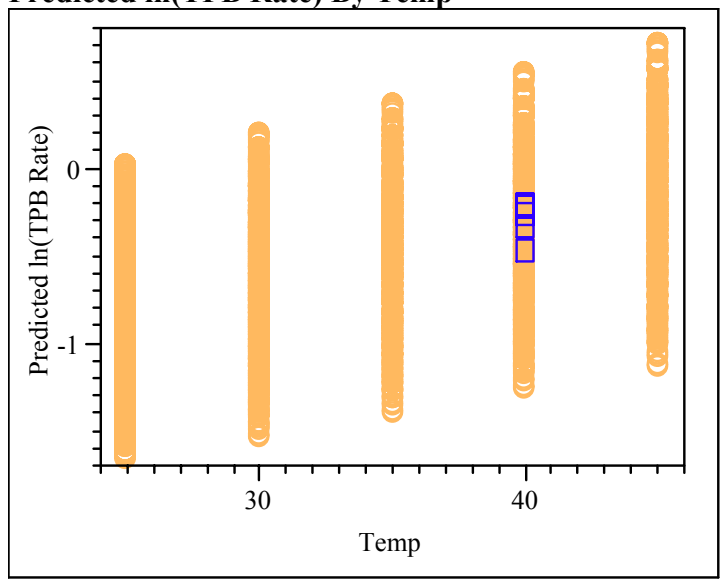

Predicted In(TPB Rate) By pH

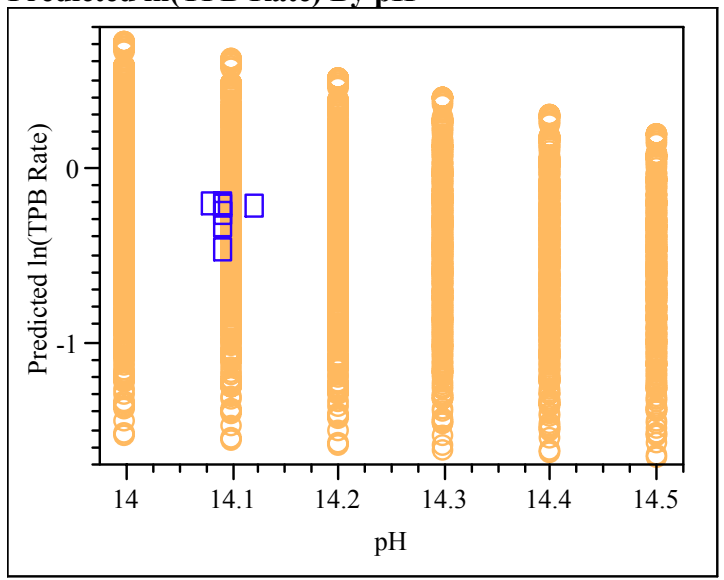

Predicted In(TPB Rate) By Na+

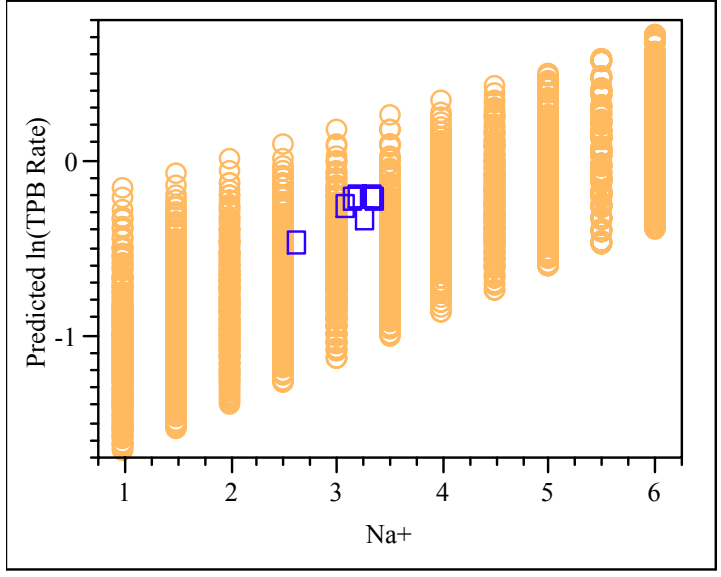

Predicted In(TPB Rate) By wt\% KTPB

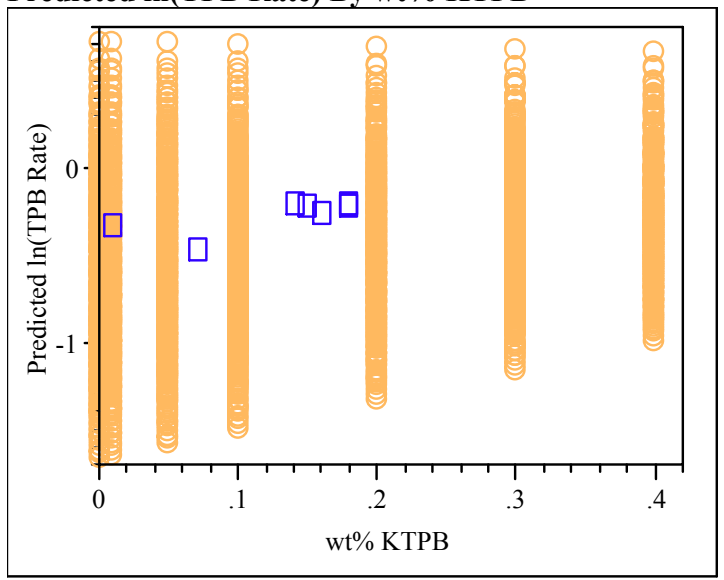

Figure 2-7 TPB Model Predictions by Factor for Grid Outlined in Table 2-3

It is interesting to note that the span of the 2,310 predicted TPB decomposition rates shown in the Figure 2-7 plots covers a range of about $10 \mathrm{X}$. The highest predicted rate is $\ln (\mathrm{TPB}$ predicted rate) $=0.729$, or $2.07 \mathrm{E}-06$ mole $\mathrm{KTPB} / \mathrm{L} /$ day, whereas the lowest predicted rate is $\ln (\mathrm{TPB}$ predicted rate $)=-1.656$, or $0.19 \mathrm{E}-06 \mathrm{~mole} \mathrm{KTPB} / \mathrm{L} / \mathrm{day}$. To help in the identification of a bounding rate over the factor space from Table 2-3 and Figure 2-7, the highest 100 predicted rates for the TPB model were determined. Table 2-4 provides the listing of the highest rates for the model along with the values of the factors that correspond to the prediction and the values providing an upper $95 \%$ bound on the average $\ln$ (rate). The highest 100 predicted rates range from $\ln (\mathrm{TPB}$ predicted rate $)=0.729$, or $2.07 \mathrm{E}-06 \mathrm{~mole} \mathrm{KTPB} / \mathrm{L} /$ day to $\ln (\mathrm{TPB}$ predicted rate $)=0.327$, or $1.39 \mathrm{E}-06 \mathrm{~mole} \mathrm{KTPB} / \mathrm{L} / \mathrm{day}$. It can be seen from the $\sim 20$ highest rates shown in Table 2-4 that conditions of highest temperature $\left(45^{\circ} \mathrm{C}\right)$, lowest $\mathrm{pH}(14-14.1)$, highest sodium molarity ( 6 to $5.5 \mathrm{M}$ ) result in the highest rates. Within these parameters, the range of wt $\%$ KTPB from 0.001 to $0.4 \mathrm{wt} \%$ has limited influence. For instance, the highest 7 rates (lines 1-7 at top of Table 2-4) under conditions of $45^{\circ} \mathrm{C}, \mathrm{pH}=14$ and $6 \mathrm{M} \mathrm{Na}+$ are in the range of 0.674 to 0.729 predicted $\ln$ (TPB Rate), or in the range of $1.96 \mathrm{E}-6$ mole $\mathrm{KTPB} / \mathrm{L} /$ day to $2.07 \mathrm{E}-6$ mole $\mathrm{KTBP} / \mathrm{L} /$ day. 
WSRC-TR-2006-00161

Revision 0

Table 2-4 Highest 100 Predicted In(rates) for TPB Model and the Factor Levels That Produced Them

\begin{tabular}{|c|c|c|c|c|c|c|c|c|}
\hline Rank & Temp & $\mathbf{p H}$ & $\mathrm{Na}+$ & wt\% KTPB & Rad/No Rad & \begin{tabular}{|c|} 
Soluble \\
TPB Present \\
\end{tabular} & \begin{tabular}{|c|} 
Predicted \\
$\ln$ (TPB Rate) \\
\end{tabular} & \begin{tabular}{|c|} 
Upper $95 \%$ \\
Limit for Mean $\ln$ (rate) \\
\end{tabular} \\
\hline 1 & 45 & 14 & 6 & 0.001 & $\mathrm{Rad}$ & No & 0.729 & 1.640 \\
\hline 2 & 45 & 14 & 6 & 0.01 & Rad & No & 0.728 & 1.636 \\
\hline 3 & 45 & 14 & 6 & 0.05 & $\operatorname{Rad}$ & No & 0.722 & 1.619 \\
\hline 4 & 45 & 14 & 6 & 0.1 & $\mathrm{Rad}$ & No & 0.715 & 1.599 \\
\hline 5 & 45 & 14 & 6 & 0.2 & Rad & No & 0.702 & 1.563 \\
\hline 6 & 45 & 14 & 6 & 0.3 & $\operatorname{Rad}$ & No & 0.688 & 1.534 \\
\hline 7 & 45 & 14 & 6 & 0.4 & $\operatorname{Rad}$ & No & 0.674 & 1.510 \\
\hline 8 & 45 & 14.1 & 6 & 0.001 & $\mathrm{Rad}$ & No & 0.623 & 1.544 \\
\hline 9 & 45 & 14.1 & 6 & 0.01 & $\mathrm{Rad}$ & No & 0.622 & 1.540 \\
\hline 10 & 45 & 14.1 & 6 & 0.05 & $\mathrm{Rad}$ & No & 0.616 & 1.523 \\
\hline 11 & 45 & 14.1 & 6 & 0.1 & $\mathrm{Rad}$ & No & 0.609 & 1.504 \\
\hline 12 & 45 & 14.1 & 6 & 0.2 & $\mathrm{Rad}$ & No & 0.596 & 1.469 \\
\hline 13 & 45 & 14 & 5.5 & 0.4 & $\mathrm{Rad}$ & No & 0.591 & 1.338 \\
\hline 14 & 45 & 14 & 5.5 & 0.3 & $\mathrm{Rad}$ & No & 0.587 & 1.345 \\
\hline 15 & 45 & 14 & 5.5 & 0.2 & $\mathrm{Rad}$ & $\mathrm{No}$ & 0.582 & 1.357 \\
\hline 16 & 45 & 14.1 & 6 & 0.3 & $\mathrm{Rad}$ & No & 0.582 & 1.440 \\
\hline 17 & 45 & 14 & 5.5 & 0.1 & $\mathrm{Rad}$ & No & 0.578 & 1.375 \\
\hline 18 & 45 & 14 & 5.5 & 0.05 & $\mathrm{Rad}$ & No & 0.575 & 1.386 \\
\hline 19 & 45 & 14 & 5.5 & 0.01 & $\mathrm{Rad}$ & $\mathrm{No}$ & 0.574 & 1.395 \\
\hline 20 & 45 & 14 & 5.5 & 0.001 & $\mathrm{Rad}$ & No & 0.573 & 1.397 \\
\hline 21 & 45 & 14.1 & 6 & 0.4 & $\mathrm{Rad}$ & No & 0.568 & 1.417 \\
\hline 22 & 40 & 14 & 6 & 0.001 & $\mathrm{Rad}$ & No & 0.556 & 1.457 \\
\hline 23 & 40 & 14 & 6 & 0.01 & $\mathrm{Rad}$ & No & 0.555 & 1.453 \\
\hline 24 & 40 & 14 & 6 & 0.05 & $\mathrm{Rad}$ & No & 0.549 & 1.437 \\
\hline 25 & 40 & 14 & 6 & 0.1 & $\mathrm{Rad}$ & $\mathrm{No}$ & 0.542 & 1.419 \\
\hline 26 & 40 & 14 & 6 & 0.2 & $\mathrm{Rad}$ & No & 0.528 & 1.387 \\
\hline 27 & 45 & 14.2 & 6 & 0.001 & $\mathrm{Rad}$ & No & 0.517 & 1.449 \\
\hline 28 & 45 & 14.2 & 6 & 0.01 & $\mathrm{Rad}$ & No & 0.516 & 1.445 \\
\hline 29 & 40 & 14 & 6 & 0.3 & $\mathrm{Rad}$ & No & 0.514 & 1.360 \\
\hline 30 & 45 & 14.2 & 6 & 0.05 & $\mathrm{Rad}$ & $\mathrm{No}$ & 0.510 & 1.429 \\
\hline 31 & 45 & 14 & 5 & 0.4 & $\mathrm{Rad}$ & No & 0.508 & 1.175 \\
\hline 32 & 45 & 14.2 & 6 & 0.1 & $\mathrm{Rad}$ & No & 0.503 & 1.410 \\
\hline 33 & 40 & 14 & 6 & 0.4 & $\mathrm{Rad}$ & No & 0.500 & 1.340 \\
\hline 34 & 45 & 14.1 & 5.5 & 0.4 & $\mathrm{Rad}$ & No & 0.490 & 1.248 \\
\hline 35 & 45 & 14.2 & 6 & 0.2 & $\mathrm{Rad}$ & No & 0.489 & 1.376 \\
\hline 36 & 45 & 14 & 5 & 0.3 & $\mathrm{Rad}$ & No & 0.485 & 1.165 \\
\hline 37 & 45 & 14.1 & 5.5 & 0.3 & $\mathrm{Rad}$ & No & 0.485 & 1.254 \\
\hline 38 & 45 & 14.1 & 5.5 & 0.2 & $\mathrm{Rad}$ & No & 0.481 & 1.266 \\
\hline 39 & 45 & 14.1 & 5.5 & 0.1 & $\mathrm{Rad}$ & $\mathrm{No}$ & 0.476 & 1.283 \\
\hline 40 & 45 & 14.2 & 6 & 0.3 & $\mathrm{Rad}$ & No & 0.476 & 1.347 \\
\hline 41 & 45 & 14.1 & 5.5 & 0.05 & $\mathrm{Rad}$ & No & 0.474 & 1.293 \\
\hline 42 & 45 & 14.1 & 5.5 & 0.01 & $\mathrm{Rad}$ & No & 0.472 & 1.302 \\
\hline 43 & 45 & 14.1 & 5.5 & 0.001 & $\mathrm{Rad}$ & No & 0.472 & 1.304 \\
\hline 44 & 45 & 14 & 5 & 0.2 & $\mathrm{Rad}$ & No & 0.463 & 1.161 \\
\hline 45 & 45 & 14.2 & 6 & 0.4 & $\mathrm{Rad}$ & No & 0.462 & 1.325 \\
\hline 46 & 40 & 14.1 & 6 & 0.001 & Rad & No & 0.458 & 1.366 \\
\hline 47 & 40 & 14.1 & 6 & 0.01 & $\mathrm{Rad}$ & $\mathrm{No}$ & 0.456 & 1.363 \\
\hline 48 & 40 & 14.1 & 6 & 0.05 & $\mathrm{Rad}$ & No & 0.451 & 1.348 \\
\hline 49 & 40 & 14.1 & 6 & 0.1 & $\mathrm{Rad}$ & No & 0.444 & 1.330 \\
\hline 50 & 45 & 14 & 5 & 0.1 & $\mathrm{Rad}$ & No & 0.440 & 1.161 \\
\hline 51 & 40 & 14.1 & 6 & 0.2 & $\mathrm{Rad}$ & No & 0.430 & 1.298 \\
\hline 52 & 45 & 14 & 5 & 0.05 & Rad & No & 0.429 & 1.162 \\
\hline 53 & 45 & 14 & 4.5 & 0.4 & $\mathrm{Rad}$ & No & 0.425 & 1.025 \\
\hline
\end{tabular}


Table 2-4 Highest 100 Predicted In(rates) for TPB Model and the Factor Levels That Produced Them (continued)

\begin{tabular}{|c|c|c|c|c|c|c|c|c|}
\hline Rank & Temp & $\mathbf{p H}$ & $\mathbf{N a}+$ & wt\% KTPB & Rad/No Rad & TPB Present & $\begin{array}{c}\text { Predicted } \\
\ln \text { (TPB Rate) } \\
\end{array}$ & $\begin{array}{c}\text { Upper } 95 \% \\
\text { Limit for Mean } \ln \text { (rate) } \\
\end{array}$ \\
\hline 54 & 45 & 14 & 5 & 0.01 & $\mathrm{Rad}$ & No & 0.419 & 1.164 \\
\hline 55 & 40 & 14 & 5.5 & 0.4 & $\mathrm{Rad}$ & No & 0.418 & 1.170 \\
\hline 56 & 45 & 14 & 5 & 0.001 & $\operatorname{Rad}$ & No & 0.417 & 1.165 \\
\hline 57 & 40 & 14.1 & 6 & 0.3 & $\operatorname{Rad}$ & No & 0.416 & 1.273 \\
\hline 58 & 40 & 14 & 5.5 & 0.3 & $\operatorname{Rad}$ & No & 0.413 & 1.173 \\
\hline 59 & 45 & 14.1 & 5 & 0.4 & Rad & No & 0.412 & 1.087 \\
\hline 60 & 45 & 14.3 & 6 & 0.001 & $\operatorname{Rad}$ & No & 0.411 & 1.354 \\
\hline 61 & 45 & 14.3 & 6 & 0.01 & $\mathrm{Rad}$ & No & 0.410 & 1.350 \\
\hline 62 & 40 & 14 & 5.5 & 0.2 & $\mathrm{Rad}$ & No & 0.409 & 1.182 \\
\hline 63 & 40 & 14 & 5.5 & 0.1 & $\mathrm{Rad}$ & No & 0.404 & 1.196 \\
\hline 64 & 45 & 14.3 & 6 & 0.05 & $\mathrm{Rad}$ & No & 0.404 & 1.334 \\
\hline 65 & 40 & 14.1 & 6 & 0.4 & $\mathrm{Rad}$ & No & 0.402 & 1.253 \\
\hline 66 & 40 & 14 & 5.5 & 0.05 & $\mathrm{Rad}$ & No & 0.402 & 1.205 \\
\hline 67 & 40 & 14 & 5.5 & 0.01 & $\mathrm{Rad}$ & No & 0.400 & 1.213 \\
\hline 68 & 40 & 14 & 5.5 & 0.001 & $\mathrm{Rad}$ & No & 0.400 & 1.215 \\
\hline 69 & 45 & 14.3 & 6 & 0.1 & $\mathrm{Rad}$ & No & 0.397 & 1.316 \\
\hline 70 & 45 & 14.1 & 5 & 0.3 & $\mathrm{Rad}$ & No & 0.389 & 1.077 \\
\hline 71 & 45 & 14.2 & 5.5 & 0.4 & $\mathrm{Rad}$ & No & 0.388 & 1.158 \\
\hline 72 & 45 & 14 & 4.5 & 0.3 & $\mathrm{Rad}$ & No & 0.384 & 0.999 \\
\hline 73 & 45 & 14.2 & 5.5 & 0.3 & $\mathrm{Rad}$ & No & 0.384 & 1.164 \\
\hline 74 & 45 & 14.3 & 6 & 0.2 & $\mathrm{Rad}$ & No & 0.383 & 1.283 \\
\hline 75 & 35 & 14 & 6 & 0.001 & $\mathrm{Rad}$ & No & 0.383 & 1.303 \\
\hline 76 & 35 & 14 & 6 & 0.01 & $\mathrm{Rad}$ & No & 0.381 & 1.300 \\
\hline 77 & 45 & 14.2 & 5.5 & 0.2 & $\mathrm{Rad}$ & No & 0.380 & 1.175 \\
\hline 78 & 35 & 14 & 6 & 0.05 & $\mathrm{Rad}$ & $\mathrm{No}$ & 0.376 & 1.286 \\
\hline 79 & 45 & 14.2 & 5.5 & 0.1 & Rad & No & 0.375 & 1.191 \\
\hline 80 & 45 & 14.2 & 5.5 & 0.05 & $\mathrm{Rad}$ & No & 0.373 & 1.201 \\
\hline 81 & 45 & 14.2 & 5.5 & 0.01 & $\mathrm{Rad}$ & No & 0.371 & 1.209 \\
\hline 82 & 45 & 14.2 & 5.5 & 0.001 & $\mathrm{Rad}$ & No & 0.371 & 1.211 \\
\hline 83 & 45 & 14.3 & 6 & 0.3 & $\mathrm{Rad}$ & No & 0.370 & 1.255 \\
\hline 84 & 35 & 14 & 6 & 0.1 & $\mathrm{Rad}$ & No & 0.369 & 1.270 \\
\hline 85 & 45 & 14.1 & 5 & 0.2 & $\mathrm{Rad}$ & No & 0.366 & 1.072 \\
\hline 86 & 40 & 14.2 & 6 & 0.001 & $\mathrm{Rad}$ & No & 0.360 & 1.277 \\
\hline 87 & 40 & 14.2 & 6 & 0.01 & $\mathrm{Rad}$ & No & 0.358 & 1.273 \\
\hline 88 & 45 & 14.3 & 6 & 0.4 & $\mathrm{Rad}$ & No & 0.356 & 1.234 \\
\hline 89 & 35 & 14 & 6 & 0.2 & $\mathrm{Rad}$ & No & 0.355 & 1.241 \\
\hline 90 & 40 & 14.2 & 6 & 0.05 & $\mathrm{Rad}$ & No & 0.353 & 1.259 \\
\hline 91 & 40 & 14.2 & 6 & 0.1 & $\mathrm{Rad}$ & No & 0.346 & 1.241 \\
\hline 92 & 45 & 14.1 & 5 & 0.1 & $\mathrm{Rad}$ & No & 0.343 & 1.071 \\
\hline 93 & 45 & 14 & 4.5 & 0.2 & $\mathrm{Rad}$ & No & 0.343 & 0.978 \\
\hline 94 & 45 & 14 & 4 & 0.4 & $\mathrm{Rad}$ & No & 0.343 & 0.893 \\
\hline 95 & 35 & 14 & 6 & 0.3 & $\mathrm{Rad}$ & No & 0.341 & 1.219 \\
\hline 96 & 40 & 14 & 5 & 0.4 & $\mathrm{Rad}$ & No & 0.335 & 1.008 \\
\hline 97 & 45 & 14.1 & 4.5 & 0.4 & $\mathrm{Rad}$ & No & 0.334 & 0.940 \\
\hline 98 & 45 & 14.1 & 5 & 0.05 & $\mathrm{Rad}$ & No & 0.332 & 1.072 \\
\hline 99 & 40 & 14.2 & 6 & 0.2 & $\mathrm{Rad}$ & No & 0.332 & 1.211 \\
\hline 100 & 35 & 14 & 6 & 0.4 & $\mathrm{Rad}$ & No & 0.327 & 1.203 \\
\hline
\end{tabular}




\subsection{RECOMMENDED SETTINGS}

As discussed in Section 2.0 and seen in Table 2-4, wt $\%$ KTPB values within the interval studied (although statistically significant in the model) have minimal influence on the predicted TPB degradation rates. In selecting the conditions from Table 2-4 to be tested in the waste qualification program, a value of $0.1 \mathrm{wt} \%$ KTPB (the mid-point of the grid of values studied) was chosen. The complete set of conditions for testing by the waste qualification program (with corresponding model prediction and upper $95 \%$ confidence limit on the expected model prediction) is given by:

\begin{tabular}{|c|c|c|c|c|c|c|c||}
\hline $\begin{array}{c}\text { Temp } \\
\left({ }^{\circ} \mathbf{C}\right)\end{array}$ & $\mathbf{p H}$ & $\begin{array}{c}\text { Na+ } \\
(\mathbf{M})\end{array}$ & wt\% KTPB & $\begin{array}{c}\text { Rad/ } \\
\text { No Rad }\end{array}$ & $\begin{array}{c}\text { TPB } \\
\text { Present }\end{array}$ & $\begin{array}{c}\text { Predicted } \\
\text { In(TPB Rate) }\end{array}$ & $\begin{array}{c}\text { Upper 95\% Limit } \\
\text { for Mean In(rate) }\end{array}$ \\
\hline 45 & 14 & 6 & 0.1 & $\mathrm{Rad}$ & No & 0.715 & 1.599 \\
\hline
\end{tabular}

For these settings of the influential factors, the model yields the highest expected TPB rate with a value of $2.04 \times 10^{-6} \mathrm{~mole} \mathrm{KTPB} / \mathrm{L} /$ day (this is the antilog of the corresponding 0.715 value in log-space for the fitted model's expected value at the selected conditions). Since the rate used in the model is expressed as a natural logarithm $(\ln [$ rate] $)$, the expected value of the model may be thought of as the average of the $\ln [$ rate]'s that would be generated by running a series of experiments - all at the conditions specified in the table above. The upper bound on this expected rate, at $95 \%$ confidence, is given by $4.95 \times 10^{-6}$ mole $\mathrm{KTPB} / \mathrm{L} /$ day (this is the antilog of the confidence limit of 1.599 in log-space for the fitted model's expected value at the selected conditions).

\subsection{CONCLUSIONS}

A TPB degradation model for use in the aggregation of Tank 48 material in Tank 50 was developed. A sensitivity study of the predictions of the model over intervals of values for the influential factors was conducted. The results from the sensitivity analysis were used to identify settings for the influential factors that can be used as the test conditions for the waste qualification program.

\subsection{REFERENCES}

[1] Maxwell, D, "Tank 48 Disposition Project Flowsheet for Aggregation Strategy 0.2 Ci/gal Cesium Max Feed," CBU-PIT-2004-0012, Revision 2, April 2006.

[2] Edwards, TB, CL Crawford, DD Walker, "TPB Decomposition Rate Models for a Compiled Set of Experimental Results (U),” SRNL-SCS-2005-00032, Revision 1, September 9, 2005.

[3] Wilmarth, WR, CL Crawford, TB Edwards, RE Eibling, DD Walker, "Potassium Tetraphenylborate Decomposition Rate Analysis," WSRC-TR-2005-00318, September 2, 2005.

[4] SAS Institute, Inc., JMP Statistics and Graphics Guide, SAS Institute, Inc., Cary, NC, 2002. 
WSRC-TR-2006-00161

Revision 0

Appendix A. 
WSRC-TR-2006-00161

Revision 0

Table A1. Compilation of SRNL Research Data Available for TPB Degradation Rate Modeling

\begin{tabular}{|c|c|c|c|c|c|c|c|c|}
\hline $\begin{array}{c}\mathrm{Rad} / \mathrm{No} \\
\mathrm{Rad}\end{array}$ & $\begin{array}{c}\text { TPB } \\
\text { Present }\end{array}$ & $\begin{array}{c}\text { Simulant } \\
/ \text { HLW }\end{array}$ & $\begin{array}{c}\text { Temp } \\
\left({ }^{\circ} \mathrm{C}\right)\end{array}$ & pH & $\begin{array}{c}\text { wt\% } \\
\text { KTPB }\end{array}$ & $\begin{array}{l}\mathrm{Na}+ \\
(\mathrm{M})\end{array}$ & $\begin{array}{c}\text { Estimate TPB } \\
\text { Rate (xE-6 moles } \\
\text { KTPB/L/day) }\end{array}$ & Notes \\
\hline Rad & Yes & HLW & 39 & 14.3 & 3.2 & 3.7 & 102 & \\
\hline $\operatorname{Rad}$ & Yes & HLW & 52 & 14.3 & 3.2 & 3.5 & 12 & \\
\hline $\operatorname{Rad}$ & Yes & HLW & 30 & 14.2 & 2.3 & 3.6 & 0.2 & \\
\hline Rad & Yes & HLW & 40 & 14.2 & 0.8 & 2.7 & 3.8 & \\
\hline $\mathrm{Rad}$ & Yes & HLW & 40 & 14.2 & 4.7 & 2.7 & 2.8 & \\
\hline $\operatorname{Rad}$ & Yes & HLW & 50 & 14.2 & 0.8 & 2.7 & 5.6 & \\
\hline $\operatorname{Rad}$ & Yes & HLW & 50 & 14.2 & 4.7 & 2.7 & 33 & \\
\hline $\operatorname{Rad}$ & Yes & HLW & 64 & 13.3 & 4.1 & 0.4 & 1500 & \\
\hline Rad & Yes & HLW & 64 & 13.6 & 4.8 & 0.9 & 3300 & \\
\hline No Rad & Yes & Simulant & 40 & 14.2 & 4 & 3 & 2.5 & MDL \\
\hline No Rad & Yes & Simulant & 40 & 14.2 & 4 & 3 & 2.5 & MDL \\
\hline No Rad & Yes & Simulant & 49 & 14.2 & 4 & 3 & 51 & \\
\hline No Rad & Yes & Simulant & 70 & 14.2 & 4 & 3 & 1000 & \\
\hline No Rad & Yes & Simulant & 45 & 14.5 & 5 & 5.5 & 97.1867008 & \\
\hline $\mathrm{Rad}$ & Yes & Simulant & 45 & 14.5 & 5 & 5.5 & 74.1687979 & \\
\hline $\operatorname{Rad}$ & Yes & Simulant & 45 & 10.4 & 5 & 5.5 & 660 & \\
\hline $\operatorname{Rad}$ & Yes & Simulant & 45 & 10.3 & 5 & 5.5 & 580 & \\
\hline $\operatorname{Rad}$ & Yes & Simulant & 45 & 10.2 & 5 & 5.5 & 510 & \\
\hline $\mathrm{Rad}$ & Yes & Simulant & 45 & 10.46 & 5 & 5.5 & 3200 & \\
\hline Rad & Yes & Simulant & 45 & 10.45 & 5 & 5.5 & 4600 & \\
\hline $\operatorname{Rad}$ & Yes & Simulant & 45 & 10.35 & 5 & 5.5 & 4100 & \\
\hline $\operatorname{Rad}$ & Yes & Simulant & 45 & 12.2 & 5 & 2.8 & 150 & \\
\hline Rad & Yes & Simulant & 45 & 12.2 & 5 & 2.8 & 160 & \\
\hline $\operatorname{Rad}$ & Yes & Simulant & 45 & 12 & 5 & 2.8 & 220 & \\
\hline $\mathrm{Rad}$ & Yes & Simulant & 45 & 11.8 & 5 & 2.8 & 28.1329923 & \\
\hline $\operatorname{Rad}$ & Yes & Simulant & 45 & 13.7 & 5 & 0.65 & 130 & \\
\hline $\mathrm{Rad}$ & Yes & Simulant & 45 & 13.7 & 5 & 0.65 & 30.6905371 & \\
\hline No Rad & Yes & Simulant & 45 & 10.3 & 5 & 0.1 & 660 & \\
\hline No Rad & Yes & Simulant & 45 & 10.1 & 5 & 0.1 & 960 & \\
\hline No Rad & Yes & Simulant & 45 & 10.2 & 5 & 0.1 & 810 & \\
\hline No Rad & Yes & Simulant & 45 & 10.4 & 5 & 0.1 & 440 & \\
\hline Rad & Yes & Simulant & 45 & 10.2 & 5 & 0.1 & 56.2659847 & \\
\hline Rad & Yes & Simulant & 45 & 9.8 & 5 & 0.1 & 61 & \\
\hline $\operatorname{Rad}$ & Yes & Simulant & 45 & 9.8 & 5 & 0.1 & 61 & \\
\hline $\mathrm{Rad}$ & Yes & Simulant & 45 & 10.1 & 2.5 & 0.1 & 51.1508951 & \\
\hline Rad & Yes & Simulant & 45 & 10.2 & 5 & 2.8 & 380 & \\
\hline $\operatorname{Rad}$ & Yes & Simulant & 45 & 9.9 & 5 & 2.8 & 360 & \\
\hline $\operatorname{Rad}$ & Yes & Simulant & 45 & 10.5 & 5 & 2.8 & 490 & \\
\hline $\operatorname{Rad}$ & Yes & Simulant & 45 & 10.2 & 2.5 & 2.8 & 560 & \\
\hline $\mathrm{Rad}$ & Yes & HLW & 45 & 14.3 & 0.9 & 5 & 230 & \\
\hline Rad & Yes & HLW & 45 & 14.4 & 0.9 & 5 & 370 & \\
\hline No Rad & Yes & Simulant & 45 & 14.3 & 5 & 5.5 & 150 & \\
\hline No Rad & Yes & Simulant & 45 & 13.8 & 5 & 5.5 & 429.667519 & \\
\hline No Rad & Yes & Simulant & 45 & 14.5 & 5 & 4.5 & 270 & \\
\hline No Rad & Yes & Simulant & 45 & 14.2 & 5 & 4.5 & 180 & \\
\hline No Rad & Yes & Simulant & 45 & 13.7 & 5 & 4.5 & 250 & \\
\hline No Rad & Yes & Simulant & 45 & 13.7 & 5 & 4.5 & 270 & \\
\hline No Rad & Yes & Simulant & 45 & 14 & 5 & 3.2 & 320 & \\
\hline No Rad & Yes & Simulant & 45 & 14 & 5 & 3.15 & 160 & \\
\hline No Rad & Yes & Simulant & 45 & 14.3 & 5 & 2.8 & 320 & \\
\hline No Rad & Yes & Simulant & 45 & 14.3 & 5 & 2.8 & 180 & \\
\hline No Rad & Yes & Simulant & 45 & 13.5 & 5 & 2.8 & 590 & \\
\hline No Rad & Yes & Simulant & 45 & 13.5 & 5 & 2.8 & 360 & \\
\hline No Rad & Yes & Simulant & 45 & 13.8 & 5 & 1.8 & 620 & \\
\hline No Rad & Yes & Simulant & 45 & 13.8 & 5 & 1.8 & 210 & \\
\hline No Rad & Yes & Simulant & 45 & 13 & 5 & 1 & 640 & \\
\hline No Rad & Yes & Simulant & 45 & 13 & 5 & 1 & 490 & \\
\hline No Rad & Yes & Simulant & 45 & 13.5 & 5 & 0.4 & 440 & \\
\hline
\end{tabular}


WSRC-TR-2006-00161

Revision 0

Table A1. Compilation of SRNL Research Data Available for TPB Degradation Rate Modeling

\begin{tabular}{|c|c|c|c|c|c|c|c|c|}
\hline $\begin{array}{c}\mathrm{Rad} / \mathrm{No} \\
\mathrm{Rad}\end{array}$ & $\begin{array}{c}\text { TPB } \\
\text { Present }\end{array}$ & $\begin{array}{c}\text { Simulant } \\
\text { /HLW }\end{array}$ & $\begin{array}{c}\text { Temp } \\
\left({ }^{\circ} \mathrm{C}\right)\end{array}$ & pH & $\begin{array}{c}\text { wt\% } \\
\text { KTPB }\end{array}$ & $\begin{array}{l}\mathrm{Na}+ \\
(\mathrm{M})\end{array}$ & $\begin{array}{c}\text { Estimate TPB } \\
\text { Rate (xE-6 moles } \\
\text { KTPB/L/day) }\end{array}$ & Notes \\
\hline No Rad & Yes & Simulant & 45 & 13.5 & 5 & 0.4 & 330 & \\
\hline No Rad & Yes & Simulant & 45 & 12.3 & 5 & 0.2 & 700 & \\
\hline No Rad & Yes & Simulant & 45 & 12.3 & 5 & 0.2 & 350 & \\
\hline No Rad & Yes & Simulant & 45 & 13.9 & 5 & 2.8 & 200 & \\
\hline No Rad & Yes & Simulant & 45 & 13.9 & 5 & 2.8 & 10 & \\
\hline No Rad & Yes & Simulant & 25 & 14.43 & 2.6 & 4.7 & 769 & \\
\hline No Rad & Yes & Simulant & 35 & 14.43 & 2.6 & 4.7 & 1150 & \\
\hline No Rad & Yes & Simulant & 45 & 14.43 & 2.6 & 4.7 & 2690 & \\
\hline Rad & No & HLW & 50 & 13.4 & 0.0034 & 0.3 & 1.7 & \\
\hline $\operatorname{Rad}$ & No & HLW & 50 & 13.7 & 0.0034 & 0.8 & 2.2 & \\
\hline Rad & No & HLW & 50 & 14 & 0.0092 & 1 & 0.43 & \\
\hline $\operatorname{Rad}$ & No & HLW & 25 & 13.4 & 0.0034 & 0.3 & 0.1 & MDL \\
\hline $\operatorname{Rad}$ & No & HLW & 50 & 14.5 & 0.0034 & 5.6 & 0.41 & \\
\hline $\operatorname{Rad}$ & No & HLW & 25 & 14.5 & 0.0034 & 5.6 & 0.1 & MDL \\
\hline Rad & No & HLW & 25 & 14 & 0.0034 & 5.6 & 0.1 & MDL \\
\hline No Rad & No & Simulant & 25 & 9 & 0.4065 & 5.6 & 13749 & \\
\hline No Rad & No & Simulant & 25 & 10 & 0.4065 & 5.6 & 8880 & MDL \\
\hline No Rad & No & Simulant & 25 & 11.5 & 0.4065 & 5.6 & 7260 & \\
\hline No Rad & No & Simulant & 25 & 13 & 0.4065 & 5.6 & 4514 & \\
\hline No Rad & No & Simulant & 25 & 14 & 0.4065 & 5.6 & 14821 & Questionable pt \\
\hline $\mathrm{Rad}$ & No & HLW & 25 & 14.2 & 0.0369 & 4.5 & 1.8 & \\
\hline $\operatorname{Rad}$ & No & HLW & 25 & 14.2 & 0.0369 & 4.5 & 2.2 & \\
\hline Rad & No & HLW & 50 & 14.2 & 0.0369 & 4.5 & 6.7 & \\
\hline Rad & No & HLW & 50 & 14.2 & 0.0369 & 4.5 & 3.1 & \\
\hline No Rad & No & Simulant & 45 & 11 & 2.32 & 2.6 & 1924 & \\
\hline No Rad & No & Simulant & 45 & 11 & 2.32 & 2.6 & 3536 & \\
\hline No Rad & No & Simulant & 45 & 7 & 2.32 & 2.6 & 3380 & \\
\hline No Rad & No & Simulant & 45 & 7 & 2.32 & 2.6 & 4576 & \\
\hline No Rad & No & Simulant & 45 & 11 & 2.32 & 2.6 & 1144 & \\
\hline No Rad & No & Simulant & 45 & 11 & 2.32 & 2.6 & 1560 & \\
\hline No Rad & No & Simulant & 45 & 8 & 2.32 & 2.6 & 5148 & \\
\hline No Rad & No & Simulant & 45 & 10 & 2.32 & 2.6 & 3900 & \\
\hline No Rad & No & Simulant & 45 & 11 & 2.32 & 2.6 & 2912 & \\
\hline No Rad & No & Simulant & 45 & 14 & 2.32 & 2.6 & 520 & \\
\hline No Rad & No & Simulant & 45 & 8 & 2.32 & 2.6 & 5148 & Pegged high \\
\hline No Rad & No & Simulant & 60 & 8 & 2.32 & 2.6 & 5148 & Pegged high \\
\hline No Rad & No & Simulant & 45 & 8 & 2.32 & 2.6 & 5148 & Pegged high \\
\hline No Rad & No & Simulant & 45 & 10 & 2.32 & 2.6 & 5148 & Pegged high \\
\hline No Rad & No & Simulant & 45 & 11 & 2.32 & 2.6 & 4368 & \\
\hline No Rad & No & Simulant & 45 & 14 & 2.32 & 2.6 & 52 & MDL \\
\hline No Rad & No & Simulant & 45 & 8 & 2.32 & 2.6 & 5148 & Pegged high \\
\hline No Rad & No & Simulant & 60 & 8 & 2.32 & 2.6 & 5148 & Pegged high \\
\hline $\operatorname{Rad}$ & No & HLW & 30 & 13.9 & 1.84 & 2.9 & 2.4 & \\
\hline No Rad & No & Simulant & 35 & 14 & 1.87 & 2.7 & 8 & MDL \\
\hline No Rad & No & Simulant & 45 & 14 & 1.87 & 2.7 & 8 & MDL \\
\hline No Rad & No & Simulant & 55 & 14 & 1.87 & 2.7 & 11 & MDL \\
\hline No Rad & No & Simulant & 45 & 13 & 1.87 & 2.7 & 13 & MDL \\
\hline No Rad & No & Simulant & 45 & 12 & 1.87 & 2.7 & 36 & MDL \\
\hline No Rad & No & Simulant & 45 & 11 & 1.87 & 2.7 & 56.6666667 & \\
\hline No Rad & No & Simulant & 45 & 11 & 0.2147 & 2 & 35 & \\
\hline No Rad & No & Simulant & 45 & 11 & 0.2147 & 2 & 55 & \\
\hline Rad & No & Simulant & 55 & 14 & 2.06 & 2.9 & 6.6 & MDL \\
\hline $\mathrm{Rad}$ & No & Simulant & 45 & 13.5 & 0.61 & 1.06 & 2.7 & MDL \\
\hline $\mathrm{Rad}$ & No & Simulant & 45 & 12.5 & 0.1 & 0.14 & 0.6 & MDL \\
\hline Rad & No & HLW & 75 & 11 & 0.82 & 8.58 & 18000 & \\
\hline Rad & No & HLW & 75 & 11 & 0.82 & 8.58 & 15000 & \\
\hline $\mathrm{Rad}$ & No & HLW & 75 & 11 & 0.82 & 8.58 & 10 & MDL \\
\hline Rad & No & HLW & 75 & 14 & 1.69 & 4.27 & 10 & MDL \\
\hline
\end{tabular}


WSRC-TR-2006-00161

Revision 0

Table A1. Compilation of SRNL Research Data Available for TPB Degradation Rate Modeling

\begin{tabular}{|c|c|c|c|c|c|c|c|c|}
\hline $\begin{array}{c}\mathrm{Rad} / \mathrm{No} \\
\mathrm{Rad}\end{array}$ & $\begin{array}{c}\text { TPB } \\
\text { Present }\end{array}$ & $\begin{array}{c}\text { Simulant } \\
\text { /HLW }\end{array}$ & $\begin{array}{c}\text { Temp } \\
\left({ }^{\circ} \mathrm{C}\right)\end{array}$ & pH & $\begin{array}{c}\text { wt\% } \\
\text { KTPB }\end{array}$ & $\begin{array}{l}\mathrm{Na}+ \\
(\mathrm{M})\end{array}$ & $\begin{array}{c}\text { Estimate TPB } \\
\text { Rate (xE-6 moles } \\
\text { KTPB/L/day) }\end{array}$ & Notes \\
\hline $\mathrm{Rad}$ & No & HLW & 75 & 14 & 1.69 & 4.27 & 10 & MDL \\
\hline Rad & No & HLW & 75 & 11 & 0.811 & 2.9 & 73 & $\mathrm{MDL}$ \\
\hline Rad & No & HLW & 75 & 11 & 0.836 & 1.38 & 1050 & \\
\hline Rad & No & HLW & 75 & 11 & 0.832 & 8.58 & 6600 & \\
\hline $\mathrm{Rad}$ & No & HLW & 75 & 11 & 0.816 & 4.27 & 18 & MDL \\
\hline $\operatorname{Rad}$ & No & HLW & 65 & 11 & 0.852 & 5.69 & 19 & \\
\hline $\mathrm{Rad}$ & No & HLW & 65 & 12 & 0.909 & 5.79 & 29 & \\
\hline Rad & No & HLW & 55 & 14 & 1.69 & 2.95 & 10 & MDL \\
\hline Rad & No & HLW & 55 & 14 & 1.88 & 2.96 & 10 & MDL \\
\hline $\operatorname{Rad}$ & No & HLW & 55 & 11 & 0.828 & 3.9 & 6 & MDL \\
\hline Rad & No & HLW & 30 & 14.06 & 1.94 & 2.99 & 2.3 & \\
\hline
\end{tabular}


WSRC-TR-2006-00161

Revision 0

Exhibit A1. Model Fit

Response In(TPB Rate)

Whole Model

Actual by Predicted Plot

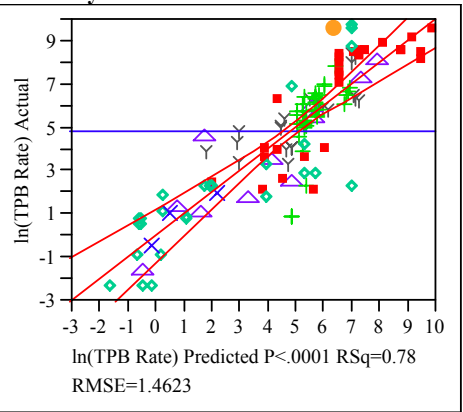

Summary of Fit

RSquare $\quad 0.775502$

RSquare Adj $\quad 0.749675$

Root Mean Square Error $\quad 1.462343$

Mean of Response $\quad 4.869122$

Observations (or Sum Wgts) 127

Analysis of Variance

Source DF Sum of Squares Mean Square F Ratio

$\begin{array}{lllll}\text { Model } & 13 & 834.7327 & 64.2102 & 30.0266\end{array}$

$\begin{array}{llll}\text { Error } & 113 & 241.6445 & 2.1384 \text { Prob }>\text { F }\end{array}$

$\begin{array}{lll}\text { C. Total } 126 & 1076.3772 & <.0001\end{array}$

Lack Of Fit

Source

Mean Square 2.33586

F Ratio

1.4670

Prob $>$ F

0.1192

Max RSq

0.9556

Parameter Estimates

Term

Intercept

Temp

$\mathrm{pH}$

wt $\%$ KTPB

$\mathrm{Na}+$

$\operatorname{Rad} /$ No $\operatorname{Rad}[$ No Rad]

TPB Present[No]

(Temp-46.5197)*(pH-12.341)

(Temp-46.5197)*Rad/No Rad[No Rad]

(Temp-46.5197)*TPB Present[No]

$(\mathrm{pH}-12.341) *(\mathrm{Na}+-3.16016)$

(wt $\%$ KTPB-2.88711)*(Na+-3.16016)

(wt\% KTPB-2.88711)*TPB Present[No]

(Na+-3.16016)*TPB Present[No]

Residual by Predicted Plot

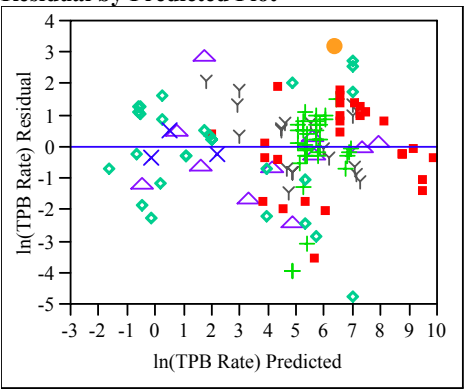

$0.111523 \quad 0.024$
Temp Leverage Plot

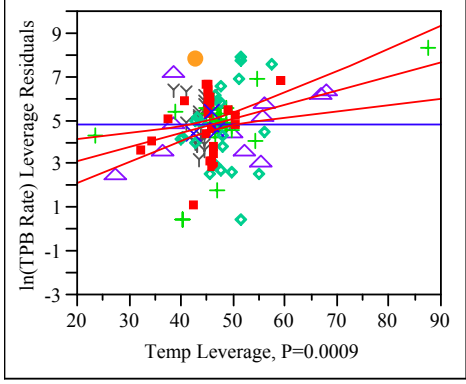

pH Leverage Plot

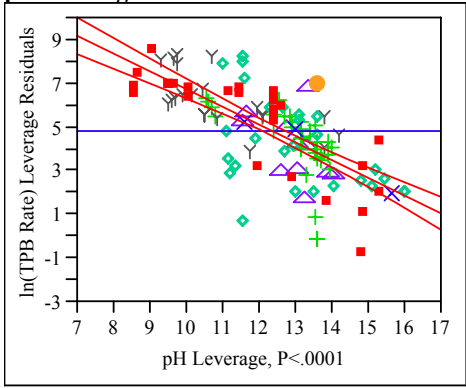

wt\% KTPB Leverage Plot

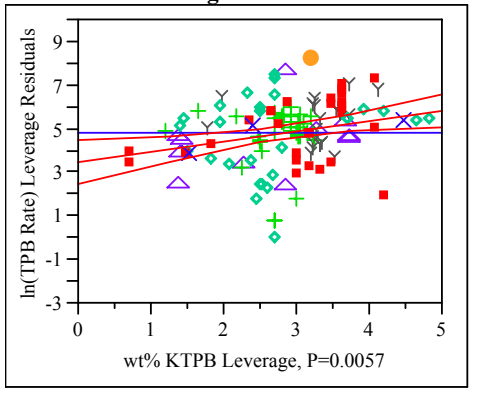

Na+ Leverage Plot

$-5.53<.0001$

$\begin{array}{ll}-2.08 & 0.0400\end{array}$

$\begin{array}{ll}-3.40 & 0.0009\end{array}$

$\begin{array}{rr}2.87 & 0.0049\end{array}$

$\begin{array}{ll}-3.45 & 0.0008\end{array}$

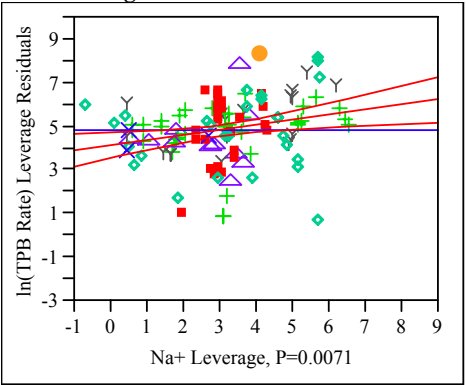




\section{Exhibit A1. Model Fit}

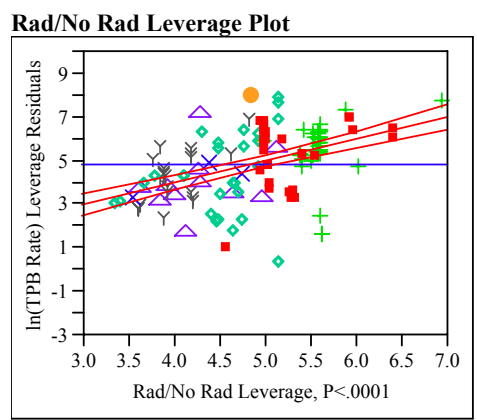

Least Squares Means Table

Level Least Sq Mean Std Error Mean

$\begin{array}{lllll}\text { No Rad } & 6.1625371 & 0.29606650 & 6.14676\end{array}$

$\begin{array}{lllll}\text { Rad } & 4.3381422 & 0.34525563 & 3.52967\end{array}$

TPB Present Leverage Plot

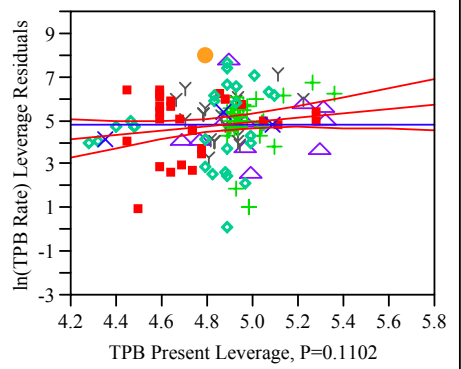

Least Squares Means Table

Level Least Sq Mean Std Error Mean

$\begin{array}{lllll}\text { No } & 4.7592728 & 0.47746690 & 4.49671\end{array}$

Yes $\quad \begin{array}{llll}5.7414065 & 0.33267098 & 5.21333\end{array}$

Temp*pH Leverage Plot

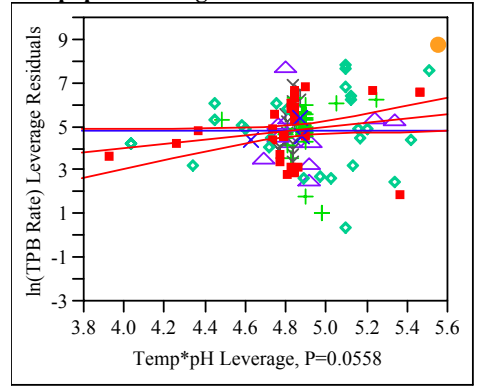

Temp*Rad/No Rad Leverage Plot

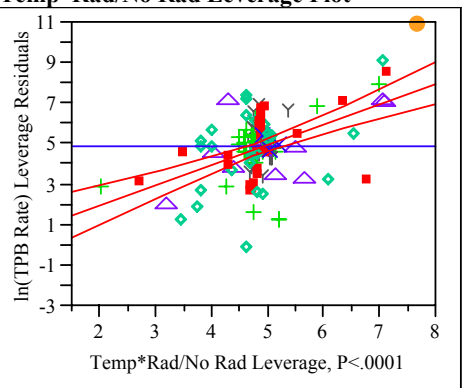

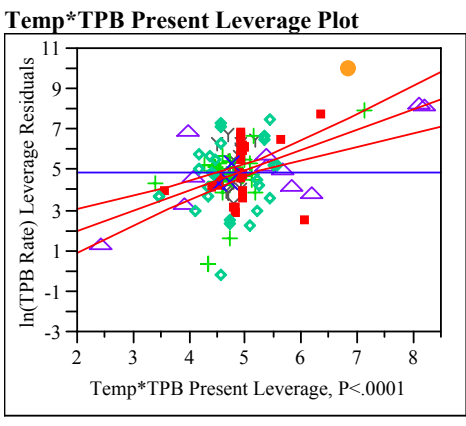

pH*Na+ Leverage Plot

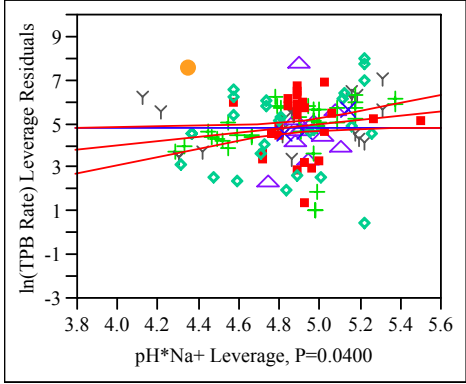

wt\% KTPB*Na+ Leverage Plot

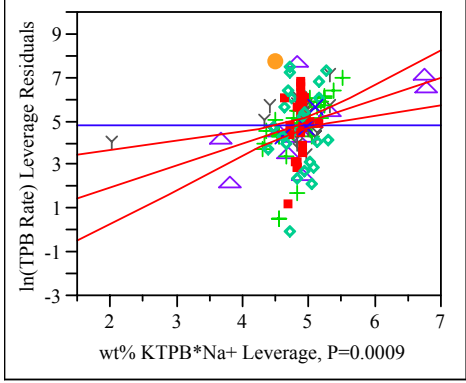

wt \% KTPB*TPB Present Leverage Plot

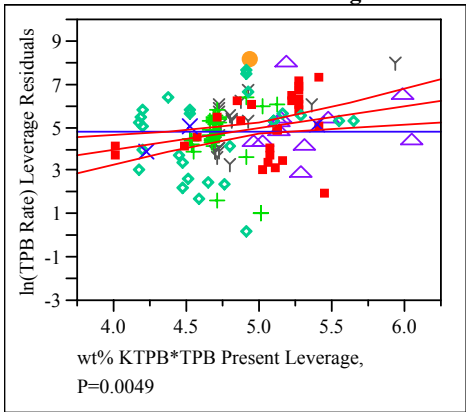

Na+*TPB Present Leverage Plot

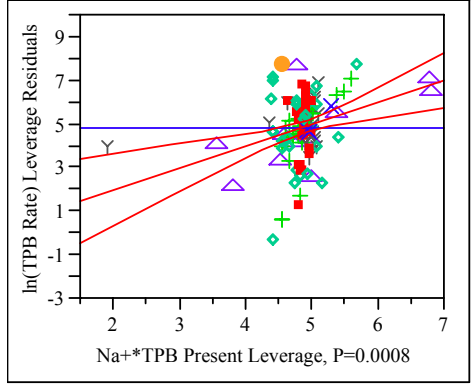


WSRC-TR-2006-00161

Revision 0

This page intentionally left blank. 
Distribution:

D. T. Conrad, 766-H

R. E. Edwards, SRNL

T. B. Edwards, 773-42A

R. E. Eibling, 999-W

J. C. Griffin, SRNL

S. P. Harris, 773-42A

D. Maxwell, 766-H

C. L. Crawford, 773-41A

D. D. Walker, SRNL

R. H. Spires, 766-H

R. C. Tuckfield, 773-42A

W. R. Wilmarth, 773-42A 